\title{
REVIEWS
}

\section{Role of Platelets in Thromboembolism in Patients with Atrial Fibrillation}

${ }^{1}$ Department of Angiology, Hypertension and Diabetology, Wroclaw Medical University, Poland

${ }^{2}$ Division of Cardiology Diseases, Mayo Clinic, Rochester, Minnesota, USA

A - research concept and design; B - collection and/or assembly of data; C - data analysis and interpretation;

$\mathbf{D}$ - writing the article; $\mathbf{E}$ - critical revision of the article; $\mathbf{F}$ - final approval of article

\begin{abstract}
Thromboembolic complications of atrial fibrillation (AF) are a major cause of morbidity and mortality but the mechanism of its process remain poorly understood. There are many as yet unanswered questions surrounding the increased thrombotic tendency in AF. One of the crucial questions is what determines the fact that a thrombus remains in the left atrium in situ in some patients, while in others it breaks off and leads to embolic complications. Recent studies indicated an important role of platelets in the left atrial's thrombus formation and suggest that the embolic potential of left atrial thromboses depends on the involvement of platelets in the process of fibrin stabilization rather than aggregation. New methods for investigating platelets function, such as the analysis of transcription activity of RNA coming from platelets contained in thrombi formed in AF, creates an opportunity for studying populations of platelets that are directly involved in homeostatic clot formation. In this paper we present current opinions on the participation of platelets in the pathogenesis of thromboembolism in patients with AF (Adv Clin Exp Med 2016, 25, 1, 163-171).
\end{abstract}

Key words: platelets, atrial fibrillation, thromboembolism.

Symptomatic thromboembolic complications are diagnosed annually on average in $5 \%$ of patients with atrial fibrillation (AF); however, the incidence rate of these complications varies over a broad range, from 0.5 to over $20 \%$ per year depending on coexisting risk factors [1]. Thromboembolic complications secondary to AF are a major cause of mortality and disability. The most common complication of AF is stroke, accounting for between $80 \%$ and over $90 \%$ of all embolic events [2]. Embolization of peripheral arteries with thrombotic material originating in the left atrium occurs much less commonly; however, in the group of patients having surgery due to peripheral embolism, $60-95 \%$ are diagnosed with AF [3].

Thrombus formation in the left atrium can be triggered by a range of factors, both inherited and acquired. It is necessary to take into account factors directly associated with the cardiac rhythm disorder and concomitant diseases [4]. The population of patients with AF is diversified. The rate of thromboembolic complications, predisposing factors and destination of embolism are different in valvular atrial fibrillation (VAF) and non-valvular atrial fibrillation (NVAF). Patients with VAF have a higher risk of thromboembolism and a higher prevalence of thrombus location within the body of the left atrium compared to NVAF. VAF is also associated with higher propensity for non-cerebral thromboemboli than in NVAF [5]. There are many as yet unanswered questions surrounding the increased thrombotic tendency in AF. One of the crucial questions is what determines the fact that a thrombus in the left atrium remains in situ in some patients, while in others it breaks off and leads to embolic complications.

As in other disorders, the risk of thromboembolic complications in AF is related to the triad of factors proposed by Rudolf Virchow: abnormalities in blood flow, endocardial/vessels wall damage and alterations in blood composition. 
Blood flow abnormalities in AF comprise primarily blood stasis resulting from a severe dysfunction of cardiac mechanical function. The left atrial appendage is considered a site especially predisposed to thrombus formation [6]. A marker of blood stasis and, at the same time, a risk factor for the development of thromboembolic complications is spontaneous echo contrast (SEC), detected by echocardiography [7]. Damage to endocardial cells in AF patients usually occurs in the left atrium and correlates with vWF concentration, which also predisposes to thrombus formation on this site [8]. Atrial fibrillation is recognized as a condition of increased thrombotic tendency due to associated blood coagulation disorders. AF patients have been shown to have elevated levels of coagulation and fibrinolysis markers (fibrinogen, D-dimer, factor VIIIc, tissue plasminogen activator, thrombin-antithrombin complex, prothrombin fragments $1+2$ ), indicators of endothelial damage (von Willebrand factor, thrombomodulin) and blood platelet activation (platelet factor 4 (PF4), beta-thromboglobulin, P-selectin), compared with individuals with sinus rhythm [9-11]. In the opinion of some authors, disorders of plasma homeostasis and blood platelet function in $\mathrm{AF}$ patients are linked to coexisting conditions such as diabetes, hypertension, cardiovascular disease and obesity [6]. Others claim that the increased activation of the coagulation process and the risk of thrombus formation in the left atrium are unrelated to coexisting diseases [12]. None of the above studies demonstrated that any of the mentioned markers of increased thrombotic tendency was specific to AF and determined embolic complications. It was only the study by Conway et al., conducted in a total of 1,321 AF patients, which showed that the level of von Willebrand factor (vWF) was a risk factor for stroke, existing independently of the history of circulatory failure, previous stroke, age and diabetes, and could be recognized as an autonomous risk factor [13]. Recently, a prospective analysis of 414 patients with NVAF provided convincing evidence of a direct correlation between vWF antigen concentration/ activity and the intensity of SEC and the presence of left atrial appendage thrombus. Consequently, vWF testing can be recommended as an additional method for the assessment of embolic risk in AF patients, complementing the CHA2DS2-VASc score [14]. The latest research indicated that blood group 0 may be protective against peripheral cardioembolic complications of NVAF, which may be related in part to reduced circulating von Willebrand levels, but cerebral thromboembolic event rates did not differ by blood group [15].

Previous studies suggest greater benefits of anticoagulants (such as vitamin $\mathrm{K}$ antagonist) in comparison to antiplatelet therapy in preventing AF-related thromboembolism. However, decreased risk for thromboembolism events during antiplatelet therapy in comparison to placebo has been also confirmed [1]. Therefore, antiplatelet drugs can be used in preventing AF-related thromboembolism (patients with $0-1$ point in CHA2DS2-VASc score).

\section{Methods for the Assessment of Platelets Involvement in the Formation of Thrombus Secondary to Atrial Fibrillation}

Platelets are anucleated shreds of megakaryocytes that play a key role in the thrombotic and inflammatory process. The normal range is 150,000 to 400,000 per cubic millimeter. Platelet population is hetrogenic in terms of its size, reactivity and susceptibility to antiplatelet therapies [16]. The young platelets that contain more megakaryocyte - derived RNA are named as reticulated platelets. Increased percentage of reticulated platelets was found in patients with acute coronary event, patients with embolic stroke and was a predictor of cardiovascular death [17-19]. Most authors report that reticulated platelets are bigger [19-21]. Therefore, an increased mean platelet volume (MPV) can be considered as the indicator of larger, more reactive platelets, and risk of thrombotic complications [18]. But there are also contradictory observation [22].

Methods aimed at measuring platelet activation detect platelet shape changes, membrane building, adhesion, aggregation, release of granular contents directly (e.g. electron microscopy, flow cytometry), and indirectly (e.g. measure the metabolites of platelets in the plasma or urine using ELISA) [23]. For a number of years, the function and/or structure of platelets in patients with $\mathrm{AF}$ was assessed by blood aggregometry (following activation with e.g. ADP, collagen) [24, 25], measurement of the concentration of secreted metabolites/products (beta-thromboglobulin, PF4, P-selectin) [10, 23, 25-27], analysis of MPV and platelet receptors in flow cytometry $[23,28]$. These studies investigated platelets circulating in peripheral blood [10, 23-29].

A major breakthrough came with the advent of methods for investigating platelets contained in thrombotic material harvested during surgical procedures using immunohistochemical tests, 
which created the possibility of assessing the role of platelets at the time of thrombus formation [30].

Advances in research methodology in such areas of study as genetics and proteomics have given rise to new opportunities of comprehensive analysis of platelet structure and function based on studying their proteome and transcriptome [31, 32]. Platelets retain megakaryocyte - derived RNA as well as proteins and molecular apparatus necessary for translation. Platelets synthesize proteins in a regulated manner, dependent on platelet activation and integrin engagement. Therefore, the profile of platelet mRNA may provide valuable insights into platelet biology, including thrombotic propensity. In response to diverse activation, platelets are able to modify gene transcription, changing their proteome [32]. The transcriptome of platelets is extremely dynamic, and represents a very sensitive marker of the functional status of platelets [31,32]. New testing methods - including extraction of pure RNA from paraffin-embedded tissues (RNeasy formalin-fixed, paraffin-embedded, RNeasy FFPE), quantitative real-time DNA assays (quantitative real-time Polymerase Chain Reaction; qRT-PCR), analysis of gene expression by reverse transcription on the RNA matrix (Reverse Transcription-PCR), serial analysis of gene expression (SAGE) - make it possible to assess the transcriptional activity of platelet genes [31-33].

Analyses of platelet proteome, transcriptome and gene expression thus offer an opportunity to comprehensively evaluate their functions in different clinical conditions. There is a range of external factors which may significantly affect the megakaryocyte-platelet system and the proteome of platelets released into blood, modifying their function. Genetic information for many blood platelet proteins is contained in the platelet RNA already at the time of their release from the megakaryocyte, e.g. for the $\mathrm{Fc}$ receptor, plasminogen activator inhibitor-1, protein kinase C [31]. However, a part of RNA remains functional in platelets released into peripheral blood, which is why platelets synthesize some proteins regardless of the activation or expression of their integrins [31]. It should, therefore, be assumed that the synthesis of proteins contained in platelets is not only a consequence of transcription at the megakaryocyte-platelet level, but it represents a marker of the status of platelets circulating in blood, and a source of information about all platelet functions, not only those related to coagulation. Mc Redmond et al. have put forth the hypothesis that the proteome of platelets reflects their transcriptome. A comparison of platelet's transcriptome and proteome with respect to the UniGene collection has demonstrated a strong link between them, and has allowed an identification of a set of 50 genes which are the most specific to platelets [31]. Rox et al. performed gene expression analysis in platelets from a single donor. They used PCR-based RNA amplification technique (switching mechanism at the 5' end of RNA templatesSMART), and tested the reliability and precision of the RNA amplification procedure by use of real-time PCR to measure quantities of specific transcripts: von Willebrand factor, A-subunit of factor XIII (F13A), glyceraldehydes-3-phosphate dehydrogenase. They proposed a protocol which made extremely small amounts of platelet RNA available for gene expression analysis in single patients [32]. Dittrich et al. established a comprehensive serial analysis expression (SAGE) library of purified human platelets. The SAGE library represented an accurate reflection of the platelet transcriptome, about 12,600 nucleus derived tags represented, 2,300 different transcripts on the level of sequence, structure, and function. These studies emphasize the richness and diversity of the platelet transcriptome [33]. Evaluation of platelet transcriptome becomes a very important clinical tool and is now emerging and as a new modality of platelet activity assessment expanding beyond traditional platelet function studies.

Recently published data demonstrates an important role of microRNA in human megakaryocytopoesis [34-39]. Despite their lack of nuclear DNA, platelets contain significant amounts of microRNA that have important functions in post-transcriptional gene regulation [37, 38, 40]. Kondkar et al. have found that differential expressed platelet microRNA altered the expression of VAMP8, a critical component of platelet granule exocytosis [35]. Nagalla et al. tested associations between microRNA profiles and platelet reactivity and the relationships between differential expressed microRNAs and target differential expressed mRNAs in health subjects. They found that human platelets express 284 microRNAs. The study provided evidence that platelet microRNA are able to repress expression of platelet protein, that microRNA may predict platelet reactivity, and that the bioinformatic approach can identify functional microRNA in platelets [37]. Osman et al. identified 281 transcripts, including 228 mature miRNAs and 53 minor miRNAs, of which six miRNAs (miR-15a, miR-339-3p, miR-365, miR495, miR-98, and miR-361-3p) were up- or downregulated in activated human platelets and indicated that encompassed 246 genes in 5 statistically significant functional clusters representing platelet miRNA regulating pathways. This study affirmed a recent microarray study reporting a wide-spread existence of miRNAs in human platelets. They observed that thrombin stimulation was associated 
with altered levels of some miRNAs in platelets [38]. These studies provide new opportunities for assessing the role of platelets in thromboembolic complications in patients with atrial fibrillation.

As mentioned above, studies of platelet functions are usually conducted based on analyses of platelets circulating in peripheral blood, before thrombus formation or after its origination. Such studies are only suitable for assessing thrombotic tendency prior to the appearance of complications, or for determining the potential involvement of platelets in events which have already occurred. In contrast, investigating the gene expression of platelets contained in the thrombus carries information about the morphological and functional status of the blood cell population which is directly involved in haemostatic plug formation. The study demonstrated that RNA extracted from FFPE platelet-rich tissues (thrombus) can be used for qRT-PCR analysis in order to determine platelet-predominate genes expression, and that RNA extracted from thrombus provides results comparable to those obtained from platelets isolated from fresh peripheral blood in patients with AF. The study indicated that RNA isolation and transcriptome analysis of platelets with far less genetic material compared to nucleated cells is also possible when several-year-old samples are used. This is a particular advantage for studying rare disease processes which may require years to acquire adequate sample numbers. Moreover, this methodology will permit investigators at remote sites to collaborate by submitting tissue samples which may include cells such as platelets which neither store nor transport well. Detailed methodology of platelet RNA isolation from peripheral blood or formalin-fixed, paraffin-embedded (FFPE) thrombi and platelet-specific genes expression assay were described in our previous publication [41].

\section{Role of Platelets in the Pathogenesis of Thromboembolic Complications in Patients with Atrial Fibrillation}

A range of external factors in AF, including blood stasis in the left atrium, elevated intra-atrial pressure (leading to a rise in pressure in pulmonary veins and an increased release of atrial natriuretic peptide) or histological lesions in the endothelial lining of atrial walls, can affect the function of blood platelets present in peripheral blood and/or modify blood platelet production by megakaryocytes [42, 43].

Studies investigating correlations between platelet function and the risk of embolic complications in patients with AF secondary to valvular pathologies and NVAF have been conducted for many years [10, 25-27, 44-51]. An increased level of platelets in patients with thrombocythemia and an association with thromboembolic events has been confirmed. Platelet activation has been especially shown to be responsible for some neurological disorders (such as transient ischemic attack, stroke, and cerebral venous thrombosis) that may complicate thrombocythemia. However, there is little accurate data on the correlation between thrombocythemia and thromboembolic complication in patients with AF [52].

$\mathrm{AF}$ in patients with a stenosis of the left venous ostium produces a 3-7-fold increase in the risk of embolism. In addition, it is associated with an elevated incidence of thrombus in the left atrium ( $16 \%$ vs. $1 \%)$ compared to patients without any cardiac arrhythmias $[8,53]$. As opposed to healthy individuals, patients suffering from rheumatic cardiac disease and AF have been shown to have higher ADP-induced platelet aggregation levels, higher concentrations of beta-thromboglobulins and PF4, signifying platelet activation, and glycocalicin (GPIb fragment) as a marker of damage to the thrombocytic membrane [25]. Some studies point to a correlation between blood platelet activation and the degree of stenosis of the left venous ostium, and a link between blood flow disorders expressed by the presence of spontaneous echo contrast on echocardiography. Kataoka et al. have shown decreased blood platelet activation following effective mitral valve valvuloplasty [26]. Other studies contradict these findings, demonstrating a rise in P-selectin and von Willebrand factor in patients who have undergone balloon valvuloplasty, and recognizing the parameters as risk factors for thromboembolic complications and an indication for introducing antiplatelet and/or antithrombotic treatment [42].

The importance of other cardiac valvular diseases as risk factors for thromboembolic complications in AF patients is not straightforward. Reports concerning the function of blood platelets and the hypercoagulable state in mitral regurgitation are conflicting. Some studies have found an increased blood platelet activation levels in patients with severe mitral regurgitation and AF [49]. Some clinical observations indicate that mitral regurgitation is not only linked to a lower incidence of spontaneous echo contrast but it even decreases the risk of stroke in patients with nonrheumatic AF [54, 55]. 
During the course of aortic valve diseases, the pathomechanism underlying raised platelet activation and elevated risk of embolism in AF patients has a different background than in mitral stenosis. It is believed that in aortic valve stenosis the formation of platelet and fibrin deposits on the valves, which constitute a potential source of embolism, is independent of AF and may be related to the atheromatous process in the aorta [56].

The mechanism leading to platelet activation in patients with NVAF is complex. Studies by Minamino et al. suggest that AF involving low concentrations of adenosine, nitric oxide and cyclic GMP may trigger platelet activation [43]. The absence of differences in P-selectin concentration between blood in the left and right atrium, and in the femoral vein and artery, suggests that AF has no impact on the variation in blood platelet activation in different sections of the circulatory system [57]. Observations about the increase in platelet activity and their implication in the pathogenesis of thrombus formation in the left atrium or embolic complications secondary to NVAF are divergent, and depend largely on the test method in use (Table 1).

Patients with NVAF have been identified with differences in blood platelet activation conditional on the flow rate in the left atrial appendage. Low flow rates $(<40 \mathrm{~cm}, \mathrm{~S}-1)$ implying the presence of stasis were associated with higher concentrations of beta-thromboglobulin and PF4, and a greater incidence of SEC and/or thrombus in the left atrium [27]. AF patients with a previous embolic incident, and patients at a high risk of embolic complications expressed by SEC or the presence of a thrombus in the left atrium were also found to have a significantly higher P-selectin and platelet CD63 expression than patients without a previous embolic incident or thrombotic lesions in the left atrium [47]. The study by Hwang et al. nonetheless has failed to establish an association between the presence of spontaneous echo contrast (SEC) on echocardiography and ADP- and collagen-induced platelet aggregation in patients with NVAF [24]. Patients suffering from NVAF, both without embolic complications and with a history of stroke, have been shown to have higher plasma concentrations of beta-thromboglobulin and PF4 than patients with a prior stroke and sinus cardiac rhythm [10]. Another finding was an increase in platelets activation expressed by the concentration of beta-thromboglobulin and PF4 during episodes of paroxysmal AF compared to periods of persisting sinus rhythm, and a positive correlation between platelets activation and duration of AF episodes [29].

A controversial issue remains the assessment of platelet activity in AF on the basis of mean platelet volume (MPV) (Table 1). MPV, a measure of platelet size, is also thought to be a determinant of their function, since large young platelets have a greater propensity for platelets clot formation [44, 46, 48, 50, 51]. Colkesen Y et al. [44] reported that mean platelet volume is elevated during paroxysmal atrial fibrillation; however, it is unclear if bigger platelets are indeed reticulated platelets [22].

Studies listed above indicate a link between platelets and the hypercoagulable state in AF patients: however, they fail to provide unambiguous evidence for the direct involvement of platelets in the process of embolization with thrombotic material originating in the left atrium (Table 1). Studies conducted at the Mayo Clinic and Wroclaw Medical University initiated a comparative analysis of the cellular and biochemical structure of thrombus present in the left atrium and peripheral embolic material in AF patients. Immunohistochemical tests showed accumulations of fibrin and blood platelets both within in situ and embolizing thrombi. Fibrin was found to be an essential component both in peripheral embolic material (65\%) and in local left atrial thrombus (52\%). Also, platelet-rich areas were shown to be more common in embolizing thrombi (39\%) than in thrombi remaining in the left atrium (19\%). The studies reported above demonstrated a difference in structure between thrombi located in the left atrium and thrombi embolizing peripheral arteries, formed during AF, and diverse involvement of blood platelets in their origination [30].

The continuation of the above observations was a genetic study comparing gene expression of blood platelets harvested from in situ left atrial thrombi and thrombi which embolize peripheral arteries. The thrombi were collected during cardiac surgery procedures or embolectomies performed in AF patients. Higher gene expression of platelet factor XIII (F13A1) in thrombi in situ in the left atrium, compared to embolizing thrombi, proved the involvement of platelets in the pathogenesis of peripheral thromboembolic complications in patients with NVAF through the effect of left atrium thrombus stabilization [41]. The majority of studies assessing the role of blood platelets in the process of coagulation focus on platelet activation, adhesion and aggregation. The involvement of blood platelets in the process of thrombus stabilization is a rarely studied aspect, even though ca. $50 \%$ of the activity of factor XIII leading to fibrin stabilization comes from platelet FXIII-A [58]. The lack of differences in gene expression for PF4, which is a determinant of platelet activation, and glycoproteins responsible for platelet adhesion (GP IX, GP Ib $\beta$ ) and aggregation (integrin $\alpha 2 b$ ) between in situ left atrial thrombi and peripheral 
Table 1. Results of platelet study in patients with AF

\begin{tabular}{|c|c|c|c|}
\hline Study & No. of patients & Platelet testing methods & Results \\
\hline $\begin{array}{l}\text { Gustafsson C } \\
\text { et al.[10] } \\
1990\end{array}$ & $\begin{array}{l}20 \text { persistent } \mathrm{AF}+\text { stroke } \\
20 \text { persistent } \mathrm{AF} \text { without stroke } \\
20 \text { sinus rhythm }+ \text { stroke } \\
20 \text { control group }\end{array}$ & $\begin{array}{l}\text { peripheral blood } \\
\mathrm{B} \text { - tromboglobulina } \\
\text { PF4 }\end{array}$ & $\begin{array}{l}\text { significantly higher tromboglobulina, PF4 } \\
\text { in AF patients (with and without stroke) } \\
\text { vs. patients with sinus rhythm and stroke } \\
\text { vs. control }\end{array}$ \\
\hline $\begin{array}{l}\text { Hwang J } \\
\text { et al.[24] } \\
1994\end{array}$ & $\begin{array}{l}119 \text { persistent AF: } \\
-39 \text { with SEC } \\
-80 \text { without SEC }\end{array}$ & $\begin{array}{l}\text { peripheral blood } \\
\text { platelet count } \\
\text { aggregation: ADP, col- } \\
\text { lagen }\end{array}$ & $\begin{array}{l}\text { no differences in platelet count and aggre- } \\
\text { gation in patients with SEC vs. without } \\
\text { SEC }\end{array}$ \\
\hline $\begin{array}{l}\text { Pongratz G } \\
\text { et al.[40] } \\
1997\end{array}$ & $\begin{array}{l}60 \text { AF: } \\
-28 \text { with embolic event } \\
-32 \text { without embolic event } \\
28 \text { control group }\end{array}$ & $\begin{array}{l}\text { peripheral blood } \\
\text { selectin P, CD63 expres- } \\
\text { sion }\end{array}$ & $\begin{array}{l}\text { significantly higher selectin } \mathrm{P}, \mathrm{CD} 63 \text { in AF } \\
\text { patients with embolic event or prothrom- } \\
\text { botic state (SEC, LAT) vs. AF without } \\
\text { embolism and control }\end{array}$ \\
\hline $\begin{array}{l}\text { Shinohara H } \\
\text { et al.[27] } \\
1997\end{array}$ & $\begin{array}{l}45 \text { persistent AF: } \\
-19 \text { with low velocity: } \\
\text { LAAFV }<40 \mathrm{~cm} / \mathrm{s} \\
\text { - } 26 \text { with high velocity: } \\
\text { LAAFV }>40 \mathrm{~cm} / \mathrm{s}\end{array}$ & $\begin{array}{l}\text { peripheral blood } \\
\mathrm{B} \text { - tromboglobulina } \\
\text { PF4 }\end{array}$ & $\begin{array}{l}\text { significantly higher B - tromboglobulina, } \\
\text { PF4 in patients with enlarged and dysfunc- } \\
\text { tioning LA and decreased LAAFV }\end{array}$ \\
\hline $\begin{array}{l}\text { Sohara H } \\
\text { et al.[29] } \\
1997\end{array}$ & $\begin{array}{l}21 \text { paroxysmal AF: } \\
10-\text { AF duration }<12 \mathrm{~h} \\
11-\text { AF duration }>12 \mathrm{~h}\end{array}$ & $\begin{array}{l}\text { peripheral blood } \\
\text { B - tromboglobulina } \\
\text { PF4 }\end{array}$ & $\begin{array}{l}\text { significantly higher } B \text { - tromboglobulina, } \\
\text { PF4 during AF vs. sinus rhythm } \\
\text { significantly higher } B \text { - tromboglobulina, } \\
\text { PF4 in patients with duration of AF }>12 \mathrm{~h}\end{array}$ \\
\hline $\begin{array}{l}\text { Goette A } \\
\text { et al.[28] } \\
2000\end{array}$ & $\begin{array}{l}19 \text { persistent } A F \\
11 \text { sinus rhythm }\end{array}$ & $\begin{array}{l}\text { peripheral blood } \\
\text { flow cytometry } \\
\text { P-selectin expression }\end{array}$ & $\begin{array}{l}\text { significantly higher P-selectin expression at } \\
\text { baseline and after platelet stimulation with } \\
\text { ADP and TRAP in patients with AF }\end{array}$ \\
\hline $\begin{array}{l}\text { Colkesen Y } \\
\text { et al.[37] } \\
2008\end{array}$ & $\begin{array}{l}103 \text { paroxysmal AF in } 24 \mathrm{~h} \\
\text { Holter } \\
87 \text { sinus rhythm in } 24 \mathrm{~h} \text { Holter }\end{array}$ & MPV & $\begin{array}{l}\text { significantly higher MPV in patients with } \\
\text { paroxysmal AF }\end{array}$ \\
\hline $\begin{array}{l}\text { Yuce M } \\
\text { et al.[44] } \\
2010\end{array}$ & $\begin{array}{l}205 \text { persistent AF } \\
96 \text { LAT or SEC in TEE } \\
109 \text { without LAT or SEC }\end{array}$ & $\begin{array}{l}\text { Peripheral blood } \\
\text { MPV } \\
\text { platelet distribution } \\
\text { weight } \\
\text { platelet count }\end{array}$ & $\begin{array}{l}\text { no difference in terms of MPV, platelet } \\
\text { distribution weight, and platelet count in } \\
\text { two groups }\end{array}$ \\
\hline $\begin{array}{l}\text { Ha SI } \\
\text { et al.[39] } \\
2011\end{array}$ & $\begin{array}{l}200 \mathrm{AF} \\
\text { end point: stroke } \\
\text { FU: } 15 \text { month } \\
\text { I Gr: } \mathrm{MPV}<8.9 \mathrm{fl} \\
\text { II Gr: } \mathrm{MPV}>8.9 \mathrm{fl}\end{array}$ & $\begin{array}{l}\text { Peripheral blood } \\
\text { MPV }\end{array}$ & $\begin{array}{l}\text { higher incidence of stroke in patients with } \\
\mathrm{MPV}>8.9 \mathrm{fl}\end{array}$ \\
\hline $\begin{array}{l}\text { Tekin G } \\
\text { et al.[41] } \\
2013\end{array}$ & $\begin{array}{l}107 \text { persistent } \mathrm{AF} \\
112 \text { normal sinus rhythm }\end{array}$ & $\begin{array}{l}\text { peripheral blood } \\
\text { MPV }\end{array}$ & $\begin{array}{l}\text { significantly higher MPV in patients with } \\
\text { AF vs. sinus rhythm }\end{array}$ \\
\hline $\begin{array}{l}\text { Turgut O } \\
\text { et al.[43] } \\
2013\end{array}$ & $\begin{array}{l}62 \text { diabetics } 2: \\
81 \text { with } \mathrm{AF} \\
81 \text { without } \mathrm{AF}\end{array}$ & $\begin{array}{l}\text { peripheral blood } \\
\text { MPV } \\
\text { platelet count }\end{array}$ & $\begin{array}{l}\text { significantly higher MPV in patients with } \\
\text { AF vs. without AF } \\
\text { no difference in platelet count }\end{array}$ \\
\hline $\begin{array}{l}\text { Goren Y } \\
\text { et al.[38] } \\
2014\end{array}$ & $\begin{array}{l}50 \text { systolic HF: } \\
\text { I Gr: with AF } \\
\text { II Gr: without AF } \\
\text { III Gr: } 50 \text { control group }\end{array}$ & $\begin{array}{l}\text { peripheral blood } \\
\text { genetic study } \\
\text { platelet miRNA-150 } \\
\text { expression }\end{array}$ & $\begin{array}{l}\text { miR-150 expression levels in platelets of } \\
\text { patients with systolic HF with AF are sig- } \\
\text { nificantly reduced and correlated to the } \\
\text { cell-free circulating levels of this miRNA. }\end{array}$ \\
\hline
\end{tabular}

LAAFV - left atrial appendage flow velocity; MPV - mean platelet volume; PF4 - platelet factor 4; LAT - left atrial thrombus; SEC - spontaneous echocontrast; TEE - transesophageal echocardiography; FU - follow-up; ADP - adenosine diphosphate; TRAP - thrombin receptor activating peptide. 
embolic material implies that the activation, adhesion and aggregation of blood platelets do not play a major role in the pathogenesis of embolic complications secondary to AF (with the except of primary thrombus formation) [41].

In the past, greater benefits of anticoagulants (vitamin $\mathrm{K}$ antagonist, direct thrombin inhibitors, FXa inhibitors) in comparison to antiplatelet therapy in preventing AF-related thromboembolism were a premise for recognizing the role of platelets to be negligible. In connection indisputable platelet participation in the formation of left atrial thrombus and embolic complications in AF, poor efficacy of antiplatelet therapy remains unclear issue. Subsequent clinical observations demonstrated that insufficient efficacy could have its origin in ASA resistance [59]. Recent studies, showing that the embolic potential of left atrial thromboses depends on the involvement of platelets in the process of fibrin stabilization rather than aggregation, warrant a fresh look on traditional pharmacological methods of preventing thromboembolic complications in AF patients.

\section{Conclusion}

Previous observations indicate the need for further research on platelets participation in the pathogenesis of thromboembolism in patients with AF, particularly determined platelets specific genetic differences will provide new insights into role of platelets in the prothrombotic status related to this arrhythmia.

The introduction of new methods for investigating blood platelet function, such as the analysis of transcription activity of platelet RNA contained in thrombi formed in AF, creates an opportunity for studying populations of platelets that are directly involved in homeostatic clot formation.

\section{References}

[1] Hart RG, Halperin JL: Atrial Fibrillation and Stroke: Concepts and Controversies. Stroke 2001, 32, 803-808.

[2] Fang MC, Singer DE, Chang Y, Hylek EM, Henault LE, Jensvold NG, Go AS: Gender differences in the risk of ischemic stroke and peripheral embolism in atrial fibrillation: the anticoagulation and risk factors in atrial fibrillation (ATRIA) study. Circulation 2005, 112, 1687-1691.

[3] Barretto PCA, Nobre MRC, Mansur AJ, Scipioni A, Ramires JAF: Peripheral Arterial Embolism. Report of hospitalized cases. Arq Bras Cardiol 2000, 74, 324-327.

[4] Hatzinikolaou-Kotsakou E, Kartasis Z, Tziakas D, Hotidis A, Stakos D, Tsatalas K, Bourikas G, Kotsakou ME, Hatserars DI: Atrial fibrillation and hypercoagulability: dependent on clinical factors or/and on genetic alterations? J Thromb Thrombolysis 2003, 16, 155-161.

[5] Blustin JM, McBane RD, Ketha SS, Wysokiński WE: Distribution of thromboembolism in valvular versus nonvalvular atrial fibrillation. Expert Rev Cardiovasc Ther 2014, 12, 1129-1132.

[6] Atrial Fibrillation Investigators: Echocardiographic predictors of stroke in patients with atrial fibrillation: a prospective study of 1066 patients from 3 clinical trials. Arch Intern Med 1998, 158, 1316-1322.

[7] Black IW, Hopkins AP, Lee LC, Walsh WF: Left atrial spontaneous echo contrast: a clinical and echocardiographic analysis. J Am Coll Cardiol 1991, 18, 398-404.

[8] Goldsmith I, Lip GYH, Blann AD, Kumar P, Carter P, Patel RL: Endocardial damage is common in the left atrial appendage of patients with mitral valve disease: implications for left atrial thrombogenesis. Eur Heart J 1999, $20,192$.

[9] Feng D, D’Agostino RB, Silberschatz H, Lipińska I, Massaro J, Levy D, Benjamin EJ, Wolf PA, Tofler GH: Hemostatic state and atrial fibrillation (The Framingham Offspring Study). Am J Cardiol 2001, 87, 168-171.

[10] Gustafsson C, Blomback M, Britton M, Hamsten A, Svensson J: Coagulation factors and the increased risk of stroke in nonvalvular atrial fibrillation. Stroke 1990, 21, 47-51.

[11] Lip GYH: The prothrombotic state in atrial fibrillation: new insights, more questions, and clear answers needed. Am Heart J 2000, 140, 348-350.

[12] Lip GYH: Does atrial fibrillation confer a hypercoagulable state? Lancet 1995, 346, 1313-1314.

[13] Conway DSG, Pearce LA, Chin BSP, Hart RG, Lip GYH: Prognostic value of plasma von Willebrand factor and soluble P-selectin as indices of endothelial damage and platelet activation in 994 patients with non-valvular atrial fibrillation. Circulation 2003, 107, 3141-3145.

[14] Ammash N, Konik EA, McBane RD, Chen D, Tange JI, Grill DE, McLeod TG, Friedman PA, Wysokiński WE: Left Atrial Blood Stasis and Von Willebrand Factor-ADAMTS13 Homeostasis in Atrial Fibrillation. Arterioscler Thromb Vasc Biol 2011, 31, 2760-2766.

[15] Blustin JM, McBane RD, Mazur M, Ammash N, Schor O, Grill DE, Wysokiński WE: The association of thromboembolic complications and blood group in patients with atrial fibrillation. Int J Cardiol 2014 (in press).

[16] Bath PM and Butterworth RJ: Platelet size: measurement, physiology and vascular disease. Blood Coagul Fibrinolysis 1996, 7, 157-161.

[17] Lakkis N, Dokainish H, Abuzahra M, Tsyboulev V, Jorgensen J, De Leon AP, Saleem A: Reticulated Platelets in Acute Coronary Syndrome: A Marker of Platelet Activity. JACC 2004, 44, 2091-2093.

[18] Mayda-Domac F, Misirli H, Yilmaz M: Prognostic role of mean platelet volume and platelet count in ischemic and hemorrhagic stroke. J Stroke Cerebrovasc Dis 2010, 19, 66-72. 
[19] Perl L, Lerman-Shivek H, Rechavia E, Vaduganathan M, Leshem-Lev D, Zemer-Wassercug N, Dadush O, Codner P, Bental T, Battler A, Kornowski R, Lev EI: Response to prasugrel and levels of circulating reticulated platelets in patients with ST-segment elevation myocardial infarction. J Am Coll Cardiol 2014, 63, 513-517.

[20] Koh KR, Yamane T, Ohta K, Hino M, Takubo T, Tatsumi N: Pathophysiological significance of simultaneous measurement of reticulated platelets, large platelets and serum thrombopoietin in non-neoplastic thrombocytopenic disorders. Eur J Haematol 1999, 63, 295-301.

[21] Guthikonda S, Alviar CL, Vaduganathan M, Arikan M, Tellez A, DeLao T, Granada JF, Dong JF, Kleiman NS, Lev EI: Role of reticulated platelets and platelet size heterogeneity on platelet activity after dual antiplatelet therapy with aspirin and clopidogrel in patients with stable coronary artery disease. J Am Coll Cardiol 2008, 52, 743-749.

[22] Hoffmann JJ, van den Broek NM, Curvers J: Reference intervals of reticulated platelets and other platelet parameters and their associations. Arch Pathol Lab Med 2013, 137, 1635-1640.

[23] Choudhury A, Chung I, Blann AD, Lip GY: Platelet surface CD62P and CD63, Mean Platelet Volume, and soluble/platelet P-selectin as index of platelet function in atrial fibrillation. J Am Coll Cardiol 2007, 49, 1957-1964.

[24] Hwang JJ, Ko FN, Li YH, Ma HM, Wu GJ: Clinical implications and factors related to left atrial spontaneous echo contrast in chronic nonvalvular atrial fibrillation. Cardiology 1994, 85, 69-75.

[25] Kunishima S, Hattori M, Kobayashi S: Activation and destruction of platelets in patients with rheumatic heart disease. Eur Heart J 1994, 15, 335-338.

[26] Kataoka H, Yano S, Mikuriya Y: Relationship of mitral valve area to hemostatic condition in rheumatic mitral stenosis. J Cardiol 1994, 24, 387-395.

[27] Shinohara H, Fukuda N, Socki T: Relationship between flow dynamics in the left atrium and hemostatic abnormalities in patients with nonvalvular atrial fibrillation. Jpn Heart J 1998, 39, 721-730.

[28] Goette A, Ittenson A, Hoffmanns P, Reek S, Hartung W, Klein H, Ansorqe S, Geller JC: Increased expression of P-selectin in patients with chronic atrial fibrillation. Pacing Clin Electrophysiol 2000, 23(11 Pt 2), 1872-1875.

[29] Sohara H, Amitani S, Kurose M, Miyahara K: Atrial fibrillation activates platelets and coagulation in a time dependent manner: A study in patients with paroxysmal atrial fibrillation. J Am Coll Cardiol 1997, 29, 106-112.

[30] Wysokinski WE, Owen WG, Fass DN, Murphy L, Patrzalek DD, McBane RD: Atrial Fibrillation and Thrombosis: Immunohistochemical Differences between in situ and Embolized. J Thromb Haemost 2004, 2, 1637-1644.

[31] McRedmond J, Park SD, Reily DF, Coppinger JA, Maguire PB, Shiels DC, Fitzgerald DJ: Integration of proteomics and genomics in platelets: a profile of platelet proteins and platelet-specific genes. Mol Cell Proteomics 2004, 3, 133-144.

[32] Rox JM, Bugert P, Müller J, Schorr A, Hanfland P, Madlener K, Pötzsch B: Gene expression in platelets from a single donor: evaluation of a PCR-based amplification technique. Clin Chem 2004, 50, 2271-2278.

[33] Wang X, Hsu MY, Steinbacher TE, Monticello TM, Schumacher WA: Quantification of platelet composition in experimental venous thrombosis by real-time polymerase chain reaction. Thromb Research 2007, 119, 593-600.

[34] Garzon R, Pichiorri F, Palumbo T, Iuliano R, Cimmino A, Aqeilan R, Volinia S, Bhatt D, Alder H, Marcucci G, Calin GA, Liu CG, Bloomfield CD, Andreeff M, Croce CM: MicroRNA fingerprints during human megakaryocytopoiesis. Proc Natl Acad Sci U S A 2006, 103, 5078-5083.

[35] Kondkar AA, Bray MS, Leal SM, Nagalla S, Liu DJ, Jin Y, Dong JF, Ren Q, Whiteheart SW, Shaw C, Bray PF: VAMP8/endobrevin is overexpressed in hyper-reactive human platelets: suggested role for platelet microRNA. J Thromb Haemost 2010, 8, 369-378.

[36] Starczynowski DT, Kuchenbauer F, Wegrzyn J, Rouhi A, Petriv O, Hansen CL, Humphries RK, Karsan A: MicroRNA-146a disrupts hematopoietic differentiation and survival. Exp Hematol 2010, 39, 167-178.

[37] Nagalla S, Shaw C, Kong X, Kondkar A, Edelstein LC, Ma L, Chen J, McKnight GS, Lopez JA, Yang L, Jin Y, Bray MS, Leal SM, Dong JF, Bray PF: Platelet microRNA-mRNA coexpression profiles correlate with platelet reactivity. Blood 2011, 117, 5189-5197.

[38] Osman A, Falker K: Characterisation of human platelet microRNA by quantitative PCR coupled with an annotation network for predicted target genes. Platelets 2011, 22, 433-441.

[39] Li H, Zhao H, Wang D, Yang R: MicroRNBA regulation in megakaryocytopoiesis. Br J Haematol 2011, 155, 298-307.

[40] Valencia-Sanchez MA, Liu J, Hannon GJ, Parker R: Control of translation and mRNA degradation by miRNAs and siRNAs. Genes Dev 2006, 20, 515-524.

[41] Gosk-Bierska I, McBane RD, Wu Y, Mruk J, Tafur A, McLeod TG, Wysokinski WE: Platelet factor XIII gene expression and embolic propensity in atrial fibrillation. Thromb Haemost 2011, 106, 75-82.

[42] Goldsmith IR, Foo LS, Blann AD, Lip GYH: Increased platelet activation and endothelial dysfunction in patients immediately following percutaneous balloon mitral valvuloplasty. Clin Cardiol 2000, 23, 587-590.

[43] Minamino T, Kitakaze M, Sato H, Asanuma H, Funaya H, Koretsune Y, Hori M: Plasma levels of nitrite/nitrate and platelet C-GMP levels are decreased in patients with atrial fibrillation. Arterioscler Thromb Vasc Biol 1997, 17, 3191-3195.

[44] Colkesen Y, Acil T, Abayli B, Yigit F, Katircibasi T, Kocum T, Demircan S, Sezgin A, Ozin B, Muderrisoglu H: Mean platelet volume is elevated during paroxysmal atrial fibrillation: a marker of increased platelet activation? Blood Coagul Fibrinolysis 2008, 19, 411-414.

[45] Goren Y, Meiri E, Hogan C, Mitchell H, Lebanony D, Salman N, Schliamser JE, Amir O: Relation of Reduced Expression of MiR-150 in Platelets to Atrial Fibrillation in Patients With Chronic Systolic Heart Failure. Am J Cardiol 2014, 113, 976-981. 
[46] Ha SI, Choi DH, Ki YJ, Yang JS, Park G, Chung JW, Koh YY, Chang KS, Hong SP: Stroke prediction using mean platelet volume in patients with atrial fibrillation. Platelets 2011, 22, 408-414.

[47] Pongratz G, Brandt-Pohlmann M, Henncke KH, Pohle C, Zink D, Gehling G, Bachmann K: Platelet activation in embolic and preembolic status of patients with non-rheumatic atrial fibrillation. Chest 1997, 111, 929-933.

[48] Tekin G, Tekin YK, Sivri N, Yetkin E: Mean platelet volume in patients with nonvalvular atrial fibrillation. Blood Coagul Fibrinolysis 2013, 24, 537-539.

[49] Tse HF, Lau CP, Cheng G: Relation between mitral regurgitation and platelet activation. J Am Coll Cardiol 1997, $30,1813-1818$.

[50] Turgut O, Zorlu A, Kilicli F, Cinar Z, Yucel H, Tandogan I, Dokmetas HS: Atrial fibrillation is associated with increased mean platelet volume in patients with type 2 diabetes mellitus. Platelets 2013, 24, 493-497.

[51] Yuce M, Cakici M, Davutoglu V, Ozer O, Sari I, Ercan S, Sucu M, Dogan A, Yavuz F: Relationship between mean platelet volume and atrial thrombus in patients with atrial fibrillation. Blood Coagul Fibrinolysis 2010, 21, $722-725$.

[52] Billot S, Kouroupi EG, Guilloux J, Cassinat B, Jardin C, Laperche T, Fenaux P, Carpentier AF, Kiladjian JJ: Neurological disorders in essential thrombocythemia. Haematologica 2011, 96, 1866-1869.

[53] Ikeda U, Yamamoto K, Shimada K: Biochemical markers of coagulation activation in mitral stenosis, atrial fibrillation and cardiomyopathy. Clin Cardiol 1997, 20, 7-10.

[54] Movsowitz C, Movsowitz HD, Jacobs LE, Meyerowitz CB, Podolsky LA, Kotler MN: Significant mitral regurgitation is protective against left atrial spontaneous echo contrast and thrombus as assessed by transesophageal echocardiography. J Am Soc Echocardiography 1993, 6, 107-114.

[55] Nakagami H, Yamamoto K, Ikeda U, Mitsuhashi T, Goto T, Shimada K: Mitral regurgitation reduces the risk of stroke in patients with nonrheumatic atrial fibrillation. Am Heart J 1998, 136, 528-532.

[56] Kaul H, Gutzweiller JP, Schnedier K, Dirsch O, Hausermann M: Aortic valve stenosis as a cause of major systemic embolism - a case report. Angiology 1998, 49, 231-234.

[57] Li-Saw-Hee FL, Blann AD, Gurney D, Lip GYH: Plasma von Willebrand factor, fibrinogen and soluble P-selectin levels in paroxysmal, persistent and permanent atrial fibrillation. Effects of cardioversion and return of left atrial function. Eur Heart J 2001, 22, 1741-1747.

[58] McDonagh J, McDonagh RP, Delage JM, Wagner RH: Factor XIII in human plasma and platelets. J Clin Invest 1969, 48, 940-946.

[59] Helgason CM, Hoff JA, Kondos GT, Brace LD: Platelet aggregation in patients with atrial fibrillation taking aspirin or warfarin. Stroke 1993, 24, 1458-1461.

\section{Address for correspondence:}

Izabela Gosk-Bierska

Department of Angiology, Hypertension and Diabetology

Wroclaw Medical University

Borowska 213

50-556 Wrocław

Poland

Tel.: +48717332200

E-mail: igoskbierska@gmail.com

Conflict of interest: None declared

Received: 14.07.2014

Revised: 30.01.2015

Accepted: 19.03.2015 